\title{
Neuron specific enolase as a possible indicator of neuron damage in children with acute meningitis
}

\author{
L. V. Pypa, R. V. Svistilnik, G. S. Moskovko, Yu. M. Lysytsia, M. M. Murhina
}

National Pirogov Memorial Medical University, Vinnytsia, Ukraine

Key words: acute meningitis, neuron-specific enolase, children.

\section{Zaporozhye} medical journal 2018; 20 (3), 354-358

DOl:

10.14739/2310-1210

2018.3.130466

E-mail:

pipa_I_v@ukr.net, rus80ua@gmail.com
Acute meningitis in children is a common cause of complications and leads to developmental disabilities. That is the reason why it is important to look for possible markers that indicate nerve tissue damage for early diagnosis, their prevention and prognosis of CNS complications.

Objective. To examine neuron specific enolase (NSE) and its diagnostic significance as an indicator of neuronal damage in children with acute meningitis.

Materials and methods. Blood samples of 40 children with acute meningitis and 30 of healthy children between the ages of 1 month to 18 years old were studied. The measurement of NSE was made from a blood serum during the first 24 hours after hospitalization by the enzyme-linked immunosorbent assay test performing. The degree of impaired consciousness was determined by the Glasgow Coma Scale. The results were processed with the Student's t-test, correlation and regression analysis methods with constructing confidence intervals.

Results. NSE levels in children with acute meningitis was 7.6 times higher than the results of healthy children, which was $22.56 \pm 1.14$ and $2.95 \pm 0.16 \mathrm{ng} / \mathrm{ml}$, respectively, $(\mathrm{P}<0.0001)(95 \% \mathrm{Cl} ; 19.19$ to 20.03). CNS complications of the disease in patients were detected in $22(55 \%)$. Patients with complications had significantly higher level of NSE than patients without complications and it was $25.35 \pm 1.61$ and $18.60 \pm 1.49 \mathrm{ng} / \mathrm{ml}$, respectively, $(P<0.01)(95 \% \mathrm{Cl} ; 5.74$ to 7.75$)$. Impaired consciousness was observed in 21 (52.5\%) patients. The content of NSE in patients with impaired consciousness was within $20.72 \pm 7.33 \mathrm{ng} / \mathrm{ml}$ and it was higher than NSE content in patients with normal consciousness that was within $16.56 \pm 4.69 \mathrm{ng} / \mathrm{ml}(\mathrm{P}<0.05)(95 \% \mathrm{Cl} ; 0.17$ to 8.14$)$. Reliable inverse and strong correlation was detected between the NSE level and the level of consciousness by the Glasgow Coma Scale, where the coefficient of determination $R^{2}=0.624$ and coefficient of correlation $r-0.785(P<0.001)(95 \% \mathrm{Cl} ;-1.08$ to -0.48$)$.

Conclusions. Thus, the data indicates that acute meningitis occurs with the brain matter damage. The blood NSE content in acute meningitis can be used as a biochemical marker for the neuronal damage severity and as a prognostic marker for the CNS complications development.
Киючові слова: гострий менінгіт, нейрон-специфічна енолаза, Аіти.

Запорізький медичний журнал. - 2018. T. 20, № 3(108), C. 354-358

\section{Нейрон-специфічна енолаза як можливий показник нейронального пошкодження при гострих менінгітах у дітей}

\section{А. В. Пипа, Р. В. Свістікьнік, Г. С. Московко, Ю. М. Аисиця, М. М. Мургіна}

Гострий менінгіт у дітей - часта причина виникнення ускладнень і розвитку інвалідизації. Тому важливим є пошук можливих маркерів пошкодження нервової тканини для ранньої діагностики та прогнозу ускладнень із боку ЦНС і їх запобігання.

Мета роботи - вивчити вміст нейрон-специфічної енолази у крові та її діагностичне значення як показника нейронального пошкодження в дітей із гострими менінгітами.

Матеріали та методи. Виконали дослідження зразків крові 40 дітей із гострими менінгітами, 30 здорових дітей віком від 1 місяця до 18 років. Нейрон-специфрічну енолазу (HCE) визначали в сироватці крові в першу добу після госпіталізації методом імуноферментного аналізу. Ступінь порушення свідомості визначали за допомогою шкали ком Глазго. Результати опрацювали за допомогою критерію Стьюдента та методами кореляційного, регресійного аналізу з побудовою довірчих інтервалів.

Результати. Рівень HCE у хворих дітей був у 7,6 раза вищим, ніж у здорових і становив 22,56 $\pm 1,14$ і 2,95 $\pm 0,16$ нг/мл відповідно ( $p<0,0001)$ (95 \% ДІ; 19,19 до 20,03). У 22 (55 \%) пацієнтів виявили ускладнення перебігу захворювання з боку ЦНС. Рівень НСЕ у пацієнтів з ускладненнями був значно вищим, ніж у пацієнтів без ускладнень і становив $25,35 \pm 1,61$ і $18,60 \pm 1,49$ нг/мл відповідно ( $<$ < 0,01) (95 \% Дl; 5,74 до 7,75). Порушення свідомості спостерігали у 21 (52,5\%) пацієнта. Вміст HCE у пацієнтів із порушенням свідомості був у межах 20,72 \pm 7,33 нг/мл і перевищував відповідний показник хворих без порушення (16,56 \pm 4,69 нг/мл) ( $<$ < 0,05) $(95 \%$ Дl; 0,17 до 8,14). Виявили вірогідний зворотний і сильний кореляційний зв'язок між рівнем HCE і рівнем свідомості за шкалою ком Глазго, де коефіцієнт детермінації $\mathrm{R}^{2}=0,624$, а коефріцієнт кореляції r становив -0,785 ( $<<0,001)(95 \%$ Дl; -1,08 до -0,48).

Висновки. Результати свідчать, що гострий менінгіт має перебіг із пошкодженням речовини головного мозку. Вміст НCE у крові при гострих менінгітах можна використовувати як біохімічний маркер вираженості нейронального пошкодження, а також як прогностичний маркер розвитку ускладнень із боку ЦНС.
Ключевые слова: острый менингит, нейрон-специфическая энолаза, Аети.

\section{Нейрон-специфическая энолаза как возможный показатель нейронального повреждения при острых менингитах у детей}

\section{А. В. Пыпа, Р. В. Свистильник, Г. С. Московко, Ю. Н. Аисица, М. Н. Мургина}

Острый менингит у детей - частая причина возникновения осложнений и развития инвалидизации. Поэтому важным является поиск возможных маркеров повреждения нервной ткани для ранней диагностики и прогноза осложнений со стороны ЦНС и их предупреждения. 
Цель работы - изучить содержание нейрон-специфической энолазы в крови и ее диагностическую значимость как показателя нейронального повреждения у детей с острыми менингитами.

Материалы и методы. Проведено исследование образцов крови 40 детей с острыми менингитами и 30 здоровых детей в возрасте от 1 месяца до 18 лет. Нейрон-специфическую энолазу (НСЭ) определяли в сыворотке крови в первые сутки после госпитализации методом иммуноферментного анализа. Степень нарушения сознания определяли с помощью шкалы ком Глазго. Обработку результатов проводили с помощью критерия Стьюдента и методами корреляционного и регрессионного анализа с построением доверительных интервалов.

Результаты. Уровень НСЭ у больных детей в 7,6 раз был выше, чем у здоровых и составил 22,56 $\pm 1,14$ и 2,95 \pm 0,16 нг/мл соответственно $p<0,0001$ (95 \% ДИ; 19,19 до 20,03). У 22 (55\%) пациентов определено наличие осложнений течения заболевания со стороны ЦНС. Уровень НСЭ у пациентов с осложнениями был значительно выше, чем у пациентов без осложнений и составлял 25,35 $\pm 1,61$ и 18,60 $\pm 1,49$ нг/мл соответственно ( $<<0,01)$ (95 \% ДИ; 5,74 до 7,75). Нарушение сознания отмечено у 21 (52,5\%) пациента. Содержание НСЭ у пациентов с нарушением сознания было в пределах $20,72 \pm$ 7,33 нг/мл и превышало такое у пациентов без нарушения (16,56 $\pm 4,69$ нг/мл) ( $><0,05)(95$ \% ДИ; 0,17 до 8,14). Установлена достоверная обратная и сильная корреляционная связь между уровнем НСЭ и уровнем сознания по шкале ком Глазго, где коэфффициент детерминации $\mathrm{R}^{2}=0,624$, а коэфффициент корреляции $r$ составляет $-0,785$ ( $\left.p<0,001\right)(95 \%$ ДИ; -1,08 до -0,48).

Выводы. Полученные данные свидетельствуют, что острый менингит протекает с повреждением вещества головного мозга. Содержание НCE в крови при острых менингитах можно использовать как биохимический маркер выраженности нейронального повреждения, а также в качестве прогностического маркера развития осложнений со стороны ЦНС.

Bacterial meningitis remains the leading cause of disability worldwide and has a high mortality rate despite the use of antibacterial therapy [1].

Delayed neurological complications may occur in 20$40 \%$ cases. Cognitive dysfunction, behavioral disorders, seizures and motor disorders are common complications of meningitis in children and adults [2].

Therefore, it is essential to find the possible markers of the nervous tissue damage in early diagnostics and prognosis of CNS complications and their prevention. Recently, the study of neuron specific enolase (NSE) as a marker of neuronal damage in various pathologies has been started.

Enolase is the key enzyme involved in glycolysis which has five isoenzymes $\alpha \alpha, \beta \beta, \gamma \gamma, \alpha \beta, \alpha \gamma$, where $\gamma \gamma$ is specifically located in neurons as well as in neuroendocrine cells, called NSE. Most of it is distributed in the CNS and makes up $1.5 \%$ of soluble protein in the brain [3]. NSE concentrates exclusively in the cytoplasm of neurons and may serve as a marker of neuronal damage [4]. In a traumatic brain injury study, NSE has proved to be a specific marker of neural tissue damage [5] and outcome prediction [6].

It has also been shown that NSE levels in the blood serum during the first days of ischemic stroke can be a useful marker for severity and early functional outcome prediction [7].

In a study of children with meningitis and encephalitis, NSE has been proven to be a specific biochemical marker of the nervous tissue pathological damage where its levels were significantly higher in more severe diseases and symptoms of CNS damage [8] as well as its levels correlated with a coma prognosis [9]

\section{Objective}

To examine the neuron specific enolase contents in blood and its diagnostic value as an indicator of neuronal damage in children with acute meningitis.

\section{Materials and methods}

The study was conducted with blood samples of 40 children with acute purulent meningitis (APM) who were treated in
Khmelnytskyi City Infectious Diseases Hospital and 30 blood samples of healthy children between the ages of 1 month to 18 years. Detection of NSE in the blood serum within the first twenty four hours after hospitalization was performed by an enzyme immunoassay using the «NSE ELISA» test systems of the DAI brand (USA). The degree of impaired consciousness was assessed by the Glasgow Coma Scale (GCS). The results were processed with the Student's t-test and constructing $95 \%$ of the confidence interval for the mean of difference, as well as the methods of correlation and regression analysis with constructing confidence intervals for correlation coefficient.

\section{Results and discussion}

NSE levels in children with the disease was 7.6 times higher than the results of healthy children, which was $22.56 \pm 1.14$ and $2.95 \pm 0.16 \mathrm{ng} / \mathrm{ml}$, respectively, $(\mathrm{P}<0.001)(95 \% \mathrm{Cl}$; 19.19 to 20.03). Some children had NSE concentration 12.5 times higher (Fig. 1).

Such significant increases of NSE concentrations can be indicative of considerable neuronal damage under various mechanisms influence, ranging from vasculitis to the cerebral edema development or other intracranial complications that can lead to nervous tissue hypoxic damage.

Significant role in neuronal damage in bacterial meningitis can play metabolic disorders of the brain. It was shown that patients with high pyruvate levels in liquor had higher levels of NSE, indicating the effect of cerebral metabolism on neuronal damage in meningitis [8].

The pathogenetic significance of neuronal damage in bacterial meningitis in adults, which correlated with a significant increase in the NSE liquor level, was also shown in the A. V. Sokhan study (2016).

While monitoring and examining of children during treatment, complications were found in 22 patients (55\%). The main CNS complications were the followings: subdural hygroma in 3 patients (13.6\%), subdural empyema in 1 patient (4.5\%), subcortical leukomalacia in 1 patient (4.5\%), hydrocephalus in 2 patients $(9.1 \%)$, cerebral edema in 3 patients (13.6\%), mental disorders (emotional disorders, asthenia, etc.) in 6 patients $(27.3 \%)$, hemiparesis in 1
Запорожский медицинский журнал. - 2018. -

T. 20, № 3(108), C. 354-358 
Table 1. NSE indicators in patients with and without CNS complications of meningitis $(\mathrm{M} \pm \sigma)$

\begin{tabular}{l|l|l|l|l} 
Observing groups & Number of patients, $\mathbf{n}$ & NSE $(\mathrm{ng} / \mathrm{ml})$ & $\mathbf{P}$ & $\mathbf{9 5} \% \mathbf{C l}$ \\
\hline With complications & 22 & $25.35 \pm 1.61$ & $<0.01$ & 5.74 to 7.75 \\
Without complications & 18 & $18.60 \pm 1.49$ & & \\
\hline
\end{tabular}

Table 2. NSE indicators in children with purulent meningitis with impaired consciousness and with normal consciousness ( $\mathrm{M} \pm \sigma$ )

\begin{tabular}{l|l|l|l|l}
\hline Observing groups & Number of patients, $\mathbf{n}$ & NSE $(\mathrm{ng} / \mathrm{ml})$ & $\mathbf{P}$ & $95 \% \mathrm{Cl}$ \\
\hline With impaired consciousness & 21 & $20.72 \pm 7.33$ & $<0.05$ & 0.17 to 8.14 \\
With normal consciousness & 19 & $16.56 \pm 4.69$ & & \\
\hline
\end{tabular}

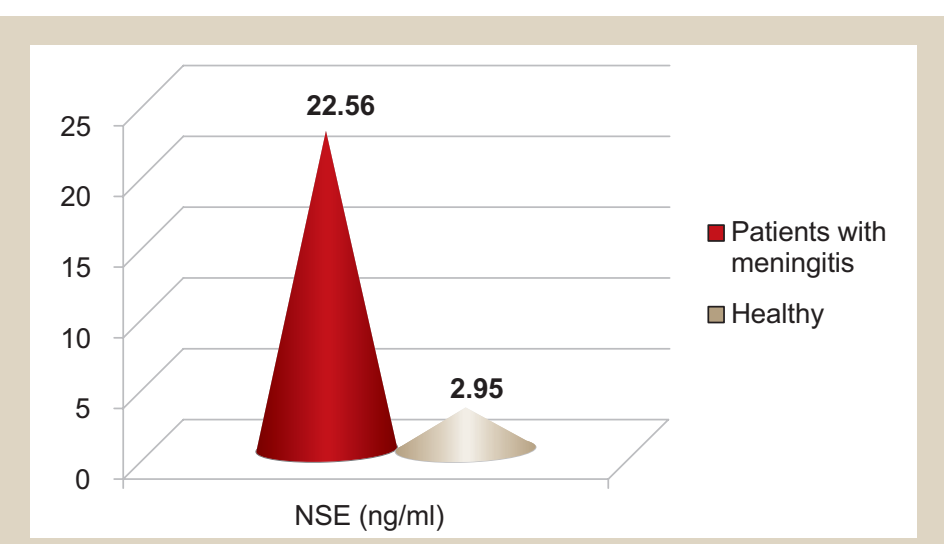

Fig. 1. The average NSE level in healthy children and children with APM.

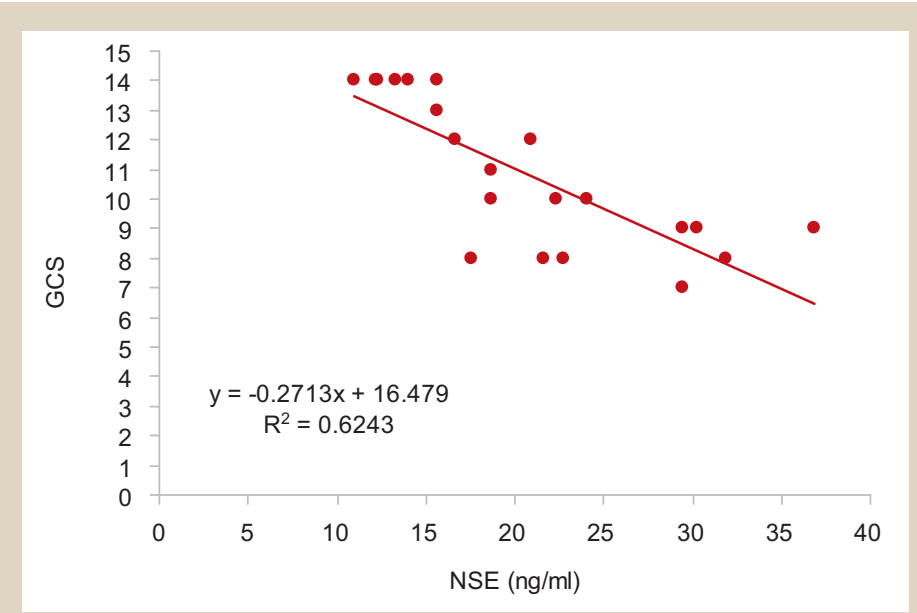

Fig. 2. Correlation between the NSE blood serum concentration and a degree of impaired consciousness by the Glasgow Coma Scale (GCS).

patient (4.5\%), deafness in 1 patient (4.5\%) and epileptic seizures in 5 patients $(22.7 \%)$.

We compared NSE levels in patients who had CNS complications whether during hospitalization or in the process of treatment with children who had no complications.

Table 1 shows NSE content among the children with meningitis who had complications comparing to the children who did not have complications. The blood serum NSE levels were significantly higher at the onset of the disease than in those children who had uncomplicated meningitis.
Higher concentrations of NSE in patients with CNS complications can also be indicative of neuronal damage important role in bacterial meningitis. In such situations, certain values of NSE can play the role of a specific marker for timely diagnosis of these complications and their targeted correction, which can reduce the effects of neuroinfection.

Other studies also determined that levels of NSE in liver and blood were in direct dependence on the meningitis course severity, and their concentrations were the greatest in patients with severe course of the disease and brain damage, which confirms the diagnostic and prognostic value of the NSE determination in bacterial meningitis $[10,11]$.

Also, in the patients' observation and examination, a focal neurological symptomatology was revealed in 13 patients, which complicated the course of the disease. Focal neurological signs manifested by the following symptoms: cranial nerves disorders in 5 patients (38.5\%), reflex changes and muscle tone disruption in 13 patients (100\%), limb paresis in 2 patients (15.4\%) and decorticate rigidity was observed in 1 patient $(7.7 \%)$.

The level of NSE in patients with neurological symptoms was observed in the range of $27.20 \pm 8.42 \mathrm{ng} / \mathrm{ml}$ and it was significantly higher than in patients without neurological symptoms that correlated to $19.72 \pm 6.85 \mathrm{ng} / \mathrm{ml}(P<0.01)$ (95\% Cl, 2.43 to $12.52 \mathrm{ng} / \mathrm{ml}$ ).

Focal neurological symptomatology can indicate the degree of nervous tissue damage in bacterial meningitis. Therefore, one can observe an appropriate correlation between its presence in children with bacterial meningitis and higher NSE blood concentrations compared with patients without focal neurological symptoms.

Impairment of consciousness was observed in 21 (52.5\%) patients, among them 7 (33.3 \%) were stunned, $10(47.6 \%)$ were in soporous state and $4(19.1 \%)$ were in comatose condition. By GCS patients with impaired consciousness were as follows: 14 points - in 6 patients, 13 points - in 1 patient, 12 points - in 2 patients, 11 points - in 1 patient, 10 points - in 3 patients, 9 points - in 3 patients, 8 points - in 3 patients and 7 points - in 1 patient.

NSE levels in patients with impaired consciousness were higher compared to conscious patients and are given in Table 2.

We used correlation and regression analysis to determine the correlation between the NSE concentration and the degree of impaired consciousness which was determined by the GCS.

In Figure 2 you can see a linear regression diagram that shows a direct correlation between the NSE blood serum concentration and a degree of impaired consciousness by the GCS.

Diagram analysis has shown certain features of the correlation between NSE and impaired consciousness. Coefficient of determination $R^{2}=0.624$ shows that changes in NSE concentration in $62.4 \%$ cases lead to changes of impaired consciousness by the GCS. The calculated correlation coefficient $r$ is $-0.785(P<0.001)(95 \% \mathrm{Cl}$ for $r$, -1.08 to -0.48$)$. Thus, reliable inverse and strong correlation was detected between NSE levels and the level of impaired consciousness by the GCS. It means that by increasing NSE concentration the level of consciousness decreases, which may indicate a significant role of neuronal damage 
in the consciousness impairment development in children with APM. Also, this may indicate a possible correlation between the degree of consciousness impairment and severity of nervous tissue damage and NSE may serve as a marker of it.

In this study it has been shown that in children with bacterial meningitis who had a disturbance of consciousness with a subsequent death, the serum and liquor NSE levels were significantly higher than in children with a favorable prognosis $(P<0.05)[9]$.

Therefore, the determination of blood serum or liquor NSE in bacterial meningitis can play a significant role in assessing the prognosis of consciousness disturbance development and even the lethal outcome of the disease.

\section{Conclusions}

Thus, the obtained data of NSE study as a possible indicator of neuronal damage shows that the majority of APM occurs with the brain matter damage.

A significant increase in blood serum NSE at the onset of the disease indicates the need for neuroprotective drugs search and use starting from the first days of the disease.

Degree of consciousness decreases by increasing NSE concentration, which indicates a significant role of neuronal damage in the consciousness impairment development in children with APM.

Taking into account the significant differences of NSE concentrations in patients with meningitis complicated by CNS disorders and patients without complications, NSE can be used not only as a marker of neuronal damage, but also as a prognostic marker of CNS complications.

Prospects for further research. Study of neuronal damage markers for disease complications and consequences prediction, as well as the search for neuroprotective drugs, that can potentially reduce the central nervous system destructive changes in children with APM, is promising and requires further research.

Conflicts of Interest: authors have no conflict of interest to declare. Конфлікт інтересів: віАсутній.

Information about authors:

Pypa L. V., MD, PhD, DSc, Professor, Head of the Department of Pediatrics, Faculty of Postgraduate Education, National Pirogov Memorial Medical University, Vinnytsia, Ukraine.

Svistilnik R. V., MD, PhD, Assistant, Department

of Neurology and Neurosurgery, Faculty of Postgraduate Education, National Pirogov Memorial Medical University, Vinnytsia, Ukraine.

Moskovko G.S., MD, PhD, Associate Professor, Head of the Department of Neurology and Neurosurgery, Faculty of Postgraduate Education, National Pirogov Memorial Medical University, Vinnytsia, Ukraine.

Lysytsia Yu. M., MD, Assistant, Department of Pediatrics, Faculty of Postgraduate Education, National Pirogov Memorial Medical University, Vinnytsia, Ukraine.

Murhina M. M., MD, Assistant, Department of Pediatrics, Faculty of Postgraduate Education, National Pirogov Memorial Medical University, Vinnytsia, Ukraine.

\section{Відомості про авторів}

Пипа А. В., А-р меА. наук, професор, зав. каф. педіатрії факультету післяАипломної освіти, Вінницький національний медичний університет імені М. І. Пирогова, Україна.
Свістільнік Р. В., канА. меА. наук, асистент каф. неврології та нейрохірургії факультету післяАипломної освіти, Вінницький національний медичний університет імені М. І. Пирогова, Україна.

Московко Г. С., канА. мед. наук, Аоцент, зав. каф. неврології та нейрохірургії факультету післяАипломної освіти, Вінницький національний медичний університет імені М. І. Пирогова, Україна.

Аисиця Ю. М., асистент каф. педіатрії факультету післядипломної освіти, Вінницький національний медичний університет імені М. І. Пирогова, Україна.

Мургина М. М., асистент каф. педіатрії факультету післяАипломної освіти, Вінницький національний меАичний університет імені М. І. Пирогова, Україна.

\section{Сведения об авторах:}

Пыпа А. В., А-р меА. наук, профессор, зав. каф. педиатрии факультета послеАипломного образования, Винницкий национальный медицинский университет имени Н. И. Пирогова, Украина.

Свистильник Р. В., канА. меА. наук, ассистент каф. неврологии и нейрохирургии факультета послеАипломного образования, Винницкий национальный медицинский университет имени Н. И. Пирогова, Украина.

Московко Г. С., канд. меА. наук, Аоцент, зав. каф. неврологии и нейрохирургии факультета послеАипломного образования, Винницкий национальный медицинский университет имени Н. И. Пирогова, Украина.

^исица Ю. Н., ассистент каф. педиатрии факультета последипломного образования, Винницкий национальный медицинский университет имени Н. И. Пирогова, Украина. Мургина М. Н., ассистент каф. педиатрии факультета послеАипломного образования, Винницкий национальный медицинский университет имени Н. И. Пирогова, Украина.

Надійшла Ао редакції / Received: 16.11.2017

Після Аоопрацювання / Revised: 20.11.2017

Прийнято Ао Аруку / Accepted: 24.11.2017

\section{References}

[1] Wang, S., Peng, L., Gai, Z., Zhang, L., Jong, A., Cao, H., \& Huang S-H. (2016) Pathogenic Triad in Bacterial Meningitis: Pathogen Invasion, NF- K B Activation, and Leukocyte Transmigration that Occur at the Blood-Brain Barrier. Front. Microbiol., 7, 148. doi: 10.3389/fmicb. 2016.00148.

[2] Chaudhuri A., Martinez-Martin, P., Kennedy, P. G., Andrew Seaton, R., Portegies, P., Bojar, M., \& Steiner, I. (2008) EFNS guideline on the management of community-acquired bacterial meningitis: report of an EFNS Task Force on acute bacterial meningitis in older children and adults. Eur J Neurol., 15(7), 649-59. doi: 10.1111/j.1468-1331. 2008.02193.x.

[3] Streitbürger, D. P., Arelin, K., Kratzsch, J., Thiery, J., Steiner, J., Villringer, A., Mueller, K., \& Schroeter, M. L. (2012) Validating Serum S100B and Neuron-Specific Enolase as Biomarkers for the Human Brain-A Combined Serum, Gene Expression and MRI Study. PLoS ONE, 7(8), 43284. doi: 10.1371/journal.pone.0043284.

[4] Rohlwink, U. K. \& Figaji, A. A. (2014) Biomarkers of Brain Injury in Cerebral Infections. Clinical Chemistry, 60(6), 823-834. doi: 10.1373/ clinchem.2013.212472.

[5] El-Maraghi, S., Yehia, H., Hossam, H., Yehia, A., \& Mowafy, H. (2013) The prognostic value of neuron specific enolase in head injury. The Egyptian Journal of Critical Care Medicine, 1, 25-32. doi: 10.1016/j. jemermed.2007.11.032.

[6] Cheng, F., Yuan, Q., Yang, J., Wang, W., \& Liu, H. (2014) The Prognostic Value of Serum Neuron-Specific Enolase in Traumatic Brain Injury: Systematic Review and Meta-Analysis. PLoS ONE, 9(9), 106680. doi: 10.1371/journal.pone.0106680.

[7] Zaheer, S., Beg, M., Rizvi, I., Islam, N., Ullah, E., \& Akhtar, N. (2013) Correlation between serum neuron specific enolase and functional neurological outcome in patients of acute ischemic stroke. Ann Indian Acad Neurol., 16(4), 504-8. doi: 10.4103/0972-2327.120442.

[8] Bartek, J. J., Thelin, E. P., Ghatan, P. H., Glimaker, M., \& Bellander, B-M. (2016) Neuron-Specific Enolase Is Correlated to Compromised Cerebral Metabolism in Patients Suffering from Acute Bacterial Meningitis; An Observational Cohort Study. PLoS One, 11(3), 0152268. doi: 10.1371/ journal.pone.0152268. 
[9] Peng, Y. \& Jiang, L. (2015) Analysis of Prognostic Factors of Children with Intracranial Infection Coma. World Journal of Neuroscience, 5 , 131-136.

[10] Sokhan, A. V. (2016) Riven neiron-spetsyfichnoi enolazy ta bilka S-100 u tserebrospinalnii ridyni khvorykh na hostri bakterialni meninhity [The level of neuron-specific enolase and S-100 protein in the cerebrospinal fluid of patients with acute bacterial meningitis]. Zaporozhye medical journal, 4(97), 73-76. doi: 10.14739/2310-1210.2016.4.79780. [in Ukrainian].

[11] Molochniy, V. P., Makarova, T. E., Golovkova, N. F., \& Obukhova, G. G. (2012) Nejrospecificheskaya enolaza i gliofibrilyarnyj kislyj protein krovi i cerebrospinal'noj zhidkosti kak marker povrezhdeniya tkani mozga pri bakterial'nykh gnojnykh meningitakh u detej [Neurospecific enolase and gliofiblar acid protein of blood and cerebrospinal fluid as a marker of cerebral tissue damage in bacteial purulent meningitis in children]. Dal'nevostochnyj medicinskij zhurnal, 2, 48-51. [in Russian]. 